\title{
Concept of convenience Marketing in Retail markets: A survey on consumers' perception Bauchi Metropolis
}

\author{
Patrick Bogoro $^{1^{*}}$ Shuaibu Hassan Usman ${ }^{2}$ \\ ${ }^{1,2}$ Faculty of Management sciences, Abubakar Tafawa Balewa University Bauchi, P. M. B 0248, Bauchi, \\ Nigeria \\ *E-mail of the corresponding author: pbogoro@gmail.com
}

\begin{abstract}
The concept of convenience Marketing has occupied high place on the consumers' shopping experience as they show the strongest growth in all the channels of retail businesses. Therefore, this study focuses on the perception of consumers within Bauchi metropolis in the use convenience marketing. The study adopted the four factors from the economic utility theory that explains the behaviors of consumers in terms of their desire time, place, possession and form utility. A total number of 301 respondents from both physical and online method of data collection were used in the study. The result from linear regression revealed the statistically significant of Time, Place and possession while Form was insignificant in measuring the outcome.
\end{abstract}

Keywords: Convenience, Consumers, Retail Businesses, The Economic Utility Theory

DOI: $10.7176 / \mathrm{JTHS} / 44-05$

Publication date:November $30^{\text {th }} 2019$

\section{Introduction}

Consumers make decisions on what to buy and what not to buy, which led marketing discipline a continous evolving one. Consumer behaviour has been in research for over 70 years where researhers and marketers have been trying various principles of marketing to identify consumers needs and wants. As it is, consumers make choice on the products and services to buy, and which not to buy, choosing which brands to use, and which brands to ignore (Richarme, 2005). Today, investigating the consumers' decision-making process in buying products in a specific location and at their convenience time is the center of interest to many researches. Therefore, it is worthy to explore the business opportunities of emerging markets through the concept of convenience. It was argued that convenience is becoming a motivator to buying decision of consumers (Sundström \& Radon, 2015). The reason for convenience becoming main player is that the "decision-making styles in emerging markets might look different from those derived from studies in mature markets in the western world" (Sundström \& Radon, 2015). The modern retailing setting presents many channels to consumers such as catalogue selling, direct selling, pure e-commerce, mobile commerce (m-commerce), \& fixed store sellings; mixed formats such as click-and-collect and pop-up-stores are also available. Today, global online retail sales have become a competitive channel to the traditional retail channels, which is driven by growth in emerging markets (eMarketer, 2014). A study indicated that consumers revealed an increasing desire to make the grocery shopping experience easier and more convenient (Market Research.com, 2019). The concern of convenience for customers is long-standing, particularly in the retailing and consumer behavior literatures. Correspondingly, there is an acknowledgement of growing consumer demand for convenience brought about by socioeconomic changes, technological progress and intensifying competition in business environments (Farquhar \& Rowley, 2009).

The convenience of marketing is associated with the non-monetary cost of the exchange to the customer. These are benefits or values that customers derive from a service or product, which the centrality of the concept of exchange to marketing theory but the concept of convenience has not, received enough attention in marketing theory. Therefore, this study is aimed at using the economic utility theory that explains the behaviors of consumers in term of their desire time, place, possession, and form utility. Usually, the term convenience encompasses a summary variable for the four utilities. This means that convenient products and/or services are made available continuously (time) within a particular area and everywhere (place) and would require almost no effort to acquire (possession) or use (form) (Brown, 1990).

\section{Related Studies}

Consumer perception has been studied in the field of marketing management that led to many companies understanding the buying decision of consumers for particular product or acquiring services. Studies on consumer 
perception were conducted by marketing managers to know more about the behavior of consumers in order to effectively communicate, tailor their advertisement campaigns and messages about their products and services (Hussain, 2017). Usually, many consumers do not know the factors that motivate them in making the buying decision on a particular product or service. Actually, it was identified that there are many factors determining the buying behavior of consumers. Hussain (2017), states that "the factors affecting consumer buying behavior include psychological, social, cultural and Personal". Therefore, studying consumer perception on convenience is worthy to identify the factors that determine the buying decision of consumers within Bauchi Metropolis in order to boost the economy of small business owners in Bauchi. It was found that convenience is a multidimensional construct (Brown, 1990). The article explains the concept of convenience as it applies to the characteristics of a product, service and idea. The concept of convenience was classified into five dimensions to include Time Dimension, Place Dimension, Acquisition Dimension, Use Dimension, and Execution Dimension (Brown, 1990). These dimensions constitute number of converging socioeconomic factors in the 1980 s to have encouraged consumers and businesses to seek convenience in the products and services they buy (Brown, 1990).

Convenience marketing in a retail concept is a means of providing a product or experience within a reasonable walk or drive, perhaps on the way home from work or in a town nearby. Maybe we could pick up that carton of milk we need in the morning, or a pint of ice cream for a late-night sugar fix. Or perhaps, if the need were not too urgent, we could order online and expect a delivery within a few days. Today, retail activities are driven by technology and an on-demand culture; younger generations of consumers have grown up with media and services that are available at the push of a button, anytime and anyplace (Fromm, 2019). Similarly, the concept of convenience is at the forefront of customer and user evaluation of service experiences and should play, a much more pivotal role in marketing theory. With increasing evidence that convenience is important to customers, it is timely to revisit the concept with a view to developing a research agenda that delivers an improved understanding of the nature of convenience (Farquhar \& Rowley, 2009).

Convenience products and services are purchased or subscript by the consumers frequently and with minimum effort and thought. Hence, such convenience purchases are also called as low involvement purchases. For buying these products, there is no planning required and these are purchased as a routine as it is useful to a very wide target market. Depending upon the utility and situation, these products are classified as staple goods (e.g. wheat, milk, and sugar), impulse goods (e.g. Chocolates, candies) and emergency goods (e.g. umbrellas, raincoats).

\section{$2.1 \quad$ Research model}

The business opportunities of convenience provide a huge advantage to economy of states. Many countries are measuring the contributions of convenience stores to the Gross Domestic product index. Thus, explanations and measurements of convenience to understand the consumer perception in selecting channel of buying products or services using technology (Internet) have been established through traditional theories on adoption such as the Theory of Reasoned Action (TRA) and the Technology Acceptance Model (TAM). These theories focus on determining the adoption and acceptance behaviors of consumers with new technology (e.g. the Internet), and their intentions to act upon it. However, these tradition theories of measuring perception on the use of new technologies may not be adequate in determining the consumers' opinion on use convenient in marketing products and services (Sundström \& Radon, 2015). Therefore, the four dimensions are adopted from the economic utility theory that explains the behaviors of consumers in term of their desire time, place, possession, and form utility as depicted in the figure 1. Generally, the term convenience encompasses summary variables for the four utilities. This means that convenient products and/or services are made available continuously (time) within a particular area and everywhere (place) and would require almost no effort to acquire (possession) or use (form). 


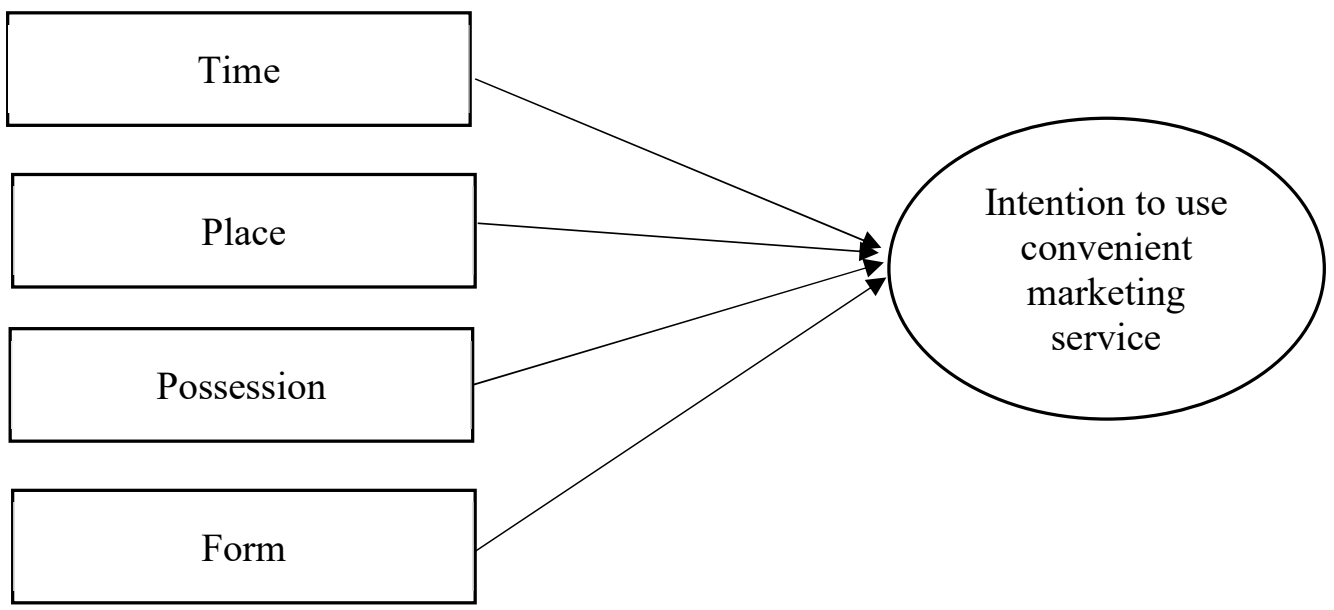

Figure 1: Research Model adapted from Lew G. Brown (1990)

Time: focuses on the products or services needed to be provided at a time within the convenient of the consumer. Some businesses open 12 hours a day while others 24 hour depend on some factors that include security, culture, place, etc. Time dimension means availability of products or services for the consumer to acquire or use on a clock time at a more convenient time but not referring timesaving to a product/service (Brown, 1990).

$\mathrm{H}_{1}$ Time has a significant relationship to the use of convenient marketing service

Place: is when products and/or services are provided in a place that is more convenient for the consumer. Therefore, providing convenient stores in neighborhood give consumers the convenient to use or acquire products/services at their immediate doors (Brown, 1990).

$\mathrm{H}_{2}$ Place has a significant relationship to the use of convenient marketing service

Possession: relies on making the whole process of acquiring or using products and/or services more easily for the consumer in term of payments and purchases. For instance, providing of Point of Sale (POS) machine to accept debit and credit cards (Brown, 1990).

$\mathrm{H}_{3}$ possession has a significant relationship to the use of convenient marketing service

Form: provides more convenient for the consumer to use products. It is where the consumer receive the specific product or service that a store offers (Brown, 1990).

$\mathrm{H}_{4}$ Form has a significant relationship to the use of convenient marketing service

\section{Research method}

This study is aimed at surveying the perception of People within Bauchi city on setting up some convenience stores on strategic places (i.e. Neighborhoods). The total population of Bauchi state as at 2006 was 4,653,066 out of which the Bauchi Metropolis was having 493,810 (Wikipedia, 2019; NPC, 2010). The sample size of this study was 381 based on estimation by Krejcie \& Morgan sampling method in 1970. The sampling technique used on the population of Bauchi metropolis was purposive sampling. This sampling method encompasses getting participants wherever you can find them. According to Saunders, Lewis, \& Thornhill in 2012 "In business studies this method can be applied in order to gain initial primary data regarding specific issues such as perception of image of a particular brand or collecting opinions of perspective customers in relation to a new design of a product" (Saunders, Lewis, \& Thornhill, 2012).

The method of data collection was both physical and online. The physical data collect was through distribution of the questionnaire to people found in the Bauchi metropolis while the online was by the used of Google form to designed the questionnaire and shared the link to various social media platforms. The method of data analysis used was linear regression. 


\section{Result}

The finding of the research is in two parts. The first part is the descriptive statistics of the respondents, while the second part is regression analysis. The descriptive statistic indicates that males have the higher number of responses with $223(74 \%)$ while females have 78(26\%). Similarly, the descriptive statistics of respondents based on educational qualification shows that HND/Degree are higher with $183(61 \%)$ follow by Postgraduate $63(21 \%)$, Diploma 31(10\%), Certificate 17(6\%), and the least is other 7(2\%). Table I depicts the descriptive statistics of the respondents.

Table I: Descriptive Statistics

\begin{tabular}{|c|c|c|c|}
\hline Variable & Description & Frequency(N) & Percent (\%) \\
\hline \multirow{3}{*}{ Gender } & Male & 223 & 74 \\
\hline & Female & 78 & 26 \\
\hline & Total & 301 & 100.0 \\
\hline \multirow{6}{*}{ Qualification } & Certificate & 17 & 6 \\
\hline & Diploma & 31 & 10 \\
\hline & HND/Degree & 183 & 61 \\
\hline & Postgraduate & 63 & 21 \\
\hline & other & 7 & 2 \\
\hline & Total & 301 & 100.0 \\
\hline
\end{tabular}

Source: field survey 2019

\subsection{Regression Analysis}

The research used the linear regression to analysis the data. The reason for using linear regression is to predict the value of a dependent variable (Intention to use Convenience marketing) based on the values of independent variables (Time, Place, Possession, and Form). The result of the regression shows ability to account for the total variation in the dependent variable. It means that the total variation of dependent variable was measured by its variance. In the table II, the model summary provides the $\mathrm{R}$ and $\mathrm{R} 2$ values. The $\mathrm{R}$ value signifies correlation and is 0.824 that shows a high degree of correlation. The $\mathrm{R} 2$ value shows the total variation in the dependent variable explained by the independent variables. The R2 is $67.9 \%$ that explain this variance. From the R2 value, which is very large, however, it can be concluded that the independent variables are adequate to measure the outcome. The Durbin-Watson statistic is 2.103 that is between 1.5 and 2.5. The result of the Durbin-Watson shows that the data is not autocorrelated, and is among the assumptions of regression that the observations should be independent. "If observations are made over time, it is likely that successive observations are related. If there is no autocorrelation (where subsequent observations are related), the Durbin-Watson statistic should be between 1.5 and 2.5" (Karadimitriou \& Marshall, 2019).

Table II: Model Summary ${ }^{\mathrm{b}}$

\begin{tabular}{|l|r|r|r|r|r|}
\hline Model & \multicolumn{1}{|c|}{$\mathrm{R}$} & R Square & $\begin{array}{c}\text { Adjusted R } \\
\text { Square }\end{array}$ & $\begin{array}{l}\text { Std. Error of the } \\
\text { Estimate }\end{array}$ & Durbin-Watson \\
\hline 1 & $.824^{\mathrm{a}}$ & .679 & .675 & .63488 & 2.103 \\
\hline
\end{tabular}

Source: field survey 2019

In the table III, which is ANOVA table. ANOVA table explains the regression equation fits the data (i.e., predicts the dependent variable). In this research, the regression result shows that there is statistical significance of model $(\mathrm{P}<0.05)$. Generally, the regression model statistically significantly predicts the outcome variable (i.e., it is a good fit for the data). 
Table III: ANOVA ${ }^{\mathrm{a}}$

\begin{tabular}{|rl|r|r|r|r|r|}
\hline Model & & Sum of Squares & df & Mean Square & \multicolumn{1}{c|}{ F } & Sig. \\
\hline \multirow{2}{*}{1} & Regression & 252.289 & 4 & 63.147 & 156.667 & $.000^{\mathrm{b}}$ \\
& Residual & 119.308 & 296 & .403 & & \\
& Total & 371.897 & 300 & & & \\
\hline
\end{tabular}

Source: field survey 2019

Table IV is the Coefficients table, which determine whether Independent variables (Time, Place, Possession, and Form) contribute statistically significantly to the model $(\mathrm{P}<0.05)$. The results from the Coefficients table shows a significant regression model among Time, Place, and Possession, with p-values less than $0.05(\mathrm{P}<0.05)$ while Form is not significant.

In the Coefficients table, time has a significant contribution to the regression model with Beta $(\beta)$ value of $.482, p$ value of 0.000 . Based on the result, convenience store need to consider time as major factor in setting up the store. Therefore, the hypothesis statement Time has a significant relationship to the use of convenience marketing is accepted. Similarly, place is significant too with $\beta$ value of $0.080, \mathrm{p}$ value of 0.037 . Therefore, Place has a significant relationship to the use of convenience marketing is accepted. In addition, Possession is statistically significant to the model with $\beta$ value 0.437 , p value of 0.000 , hence, the hypothesis statement that says possession has a significant relationship to the use of convenient marketing is accepted. On the other hand, Form is not significant to the setting up convenience marketing with $\beta$ value of $0.002, p$ value of 0.981 . Therefore, the hypothesis statement Form has a significant relationship to the use of convenient marketing is rejected.

Table IV: Coefficients ${ }^{\mathrm{a}}$

\begin{tabular}{|c|c|c|c|c|c|}
\hline \multirow[t]{2}{*}{ Model } & \multicolumn{2}{|c|}{ Unstandardized Coefficients } & \multirow{2}{*}{\begin{tabular}{|l} 
Standardized \\
Coefficients
\end{tabular}} & \multirow[t]{2}{*}{$\mathrm{t}$} & \multirow[t]{2}{*}{ Sig. } \\
\hline & $\bar{B}$ & Std. Error & & & \\
\hline (Constant) & .667 & .128 & & 5.212 & .000 \\
\hline Time & .498 & .077 & .482 & 6.037 & .000 \\
\hline Place & -.159 & .072 & -.80 & -1.289 & .037 \\
\hline possession & .276 & .086 & .437 & 4.812 & .000 \\
\hline Form & -.129 & .075 & -.002 & -0.024 & .981 \\
\hline
\end{tabular}

Source: field survey 2019

\section{Conclusion}

This study shows a promising result for convenience marketing strategy with four of the constructs measuring the intention to use convenient marketing service within Bauchi metropolis, which were statistically significant except for the Form. It is recommended that the concept of convenience is at the fore-front of customer and user evaluations of service experiences and it should play a much more pivotal role in marketing theory.

\section{References}

Brown, L. G., 1990. Convenience in Services Marketing. Journal of Services Marketing, 4(1), pp. 53-59. eMarketer, 2014. Global B2C Ecommerce Sales to Hit S1.5 Trillion "is Year Driven by Growth in Emerging Markets..

Available at: $\mathrm{m}$ h'p:/www.emarketer.com/Article/Global-B2C-Ecommerce-Sales-Hit-3615Trillion-"is-Year-Driven-by-Growth-Emerging-Markets/1010575 Farquhar, J. D. \& Rowley, J., 2009. Convenience: a services perspective. Marketing Theory , pp. 425-438.

Fromm, J., 2019. Marketing Convenience To The Modern Consumer. [Online] Available at: https://www.forbes.com/sites/jefffromm/2019/01/04/marketing-convenience-to-themodern-consumer/\#705af38f127f

Hussain, M., 2017. Study on Consumer Decision Making process in the Selection of Home Cleaning Company, Helsinki: International Business, JAMK University of Applied Sciences.

Karadimitriou, S. M. \& Marshall, E., 2019. Outliers, Durbin-Watson and interactions for regression in SPSS. 
[Online]

Available

https://www.sheffield.ac.uk/polopoly fs/1.531431!/file/MASHRegression Further SPSS.pdf

Market Research.com, 2019. 23771 Reports from Euromonitor International. [Online] Available at: https://www.marketresearch.com/Euromonitor-International-v746/

NPC, 2010. Population by State and Sex. population.gov.ng. [Online] Available at: http://www.population.gov.ng/files/nationafinal.pdf

Richarme, M., 2005. Consumer Decision-Making Models, Strategies, and Theories, Oh My!. [Online] Available at: https://www.decisionanalyst.com/whitepapers/decisionmaking/

Saunders, M., Lewis, P. \& Thornhill, A., 2012. Research Methods for Business Students. 6th ed. s.1.:Pearson Education Limited.

Sundström, M. \& Radon, A., 2015. Utilizing the concept of convenience as a business opportunity in Emerging Markets. Organizations and Markets in Emerging Economies, pp. 7-21.

Wikipedia, 2019. List of Nigerian states by population. [Online] Available at: https://en.wikipedia.org/wiki/List_of_Nigerian_states_by_population\#cite_note-1 